\title{
Apricot Probiotic Drinking Yoghurt Supplied with Inulin and Oat Fiber
}

\author{
Mutlu B. Güler-Akın*, Ismet Ferliarslan, Musa Serdar Akın \\ Department of Food Engineering, Agricultural Faculty, Harran University, Şanlıurfa, Turkey \\ Email: ${ }^{\star}$ mutluakin@harran.edu.tr
}

How to cite this paper: Güler-Akın, M.B., Ferliarslan, I. and Akın, M.S. (2016) Apricot Probiotic Drinking Yoghurt Supplied with Inulin and Oat Fiber. Advances in Microbiology, 6, 999-1009.

http://dx.doi.org/10.4236/aim.2016.614094

Received: October 17, 2016

Accepted: December 4, 2016

Published: December 8, 2016

Copyright $\odot 2016$ by authors and Scientific Research Publishing Inc. This work is licensed under the Creative Commons Attribution International License (CC BY 4.0).

http://creativecommons.org/licenses/by/4.0/ (c) (i) Open Access

\begin{abstract}
In this study, the effects of different amounts of inulin and oat fiber addition on the properties of apricot probiotic drinking yoghurt (APDY) were investigated. Seven different APDY was produced. Six of them were produced by the addition of $0.5 \%$, $1 \%$ and $2 \%$ inulin $(B, C, D)$ and oat fiber $(E, F, G)$ and one of them was produced as control sample. Pasteurized apricot pureed and sugar (10\%) was added to fermented milk beverage. APDYs were analysed 1, 7, 14 and 21 days after production. Addition of fiber to APDYs had significantly affected on the $\mathrm{pH}$, titratable acidity, water holding capacity, S. thermophilus, L. acidophilus Bifidobacterium BB-12 counts, and sensorial properties of the samples $(\mathrm{p}<0.01)$. $\mathrm{pH}$ values decreased titratable acidity, water holding capasity, the viscosity values, $L$. acidophilus and Bifidobacterium BB-12 counts increase by the addition of fiber into samples.
\end{abstract}

\section{Keywords}

Probiotic Drinking Yoghurt, Inulin, Oat Fiber

\section{Introduction}

Because of their attributed health benefits, probiotic bacteria have been increasingly included in yoghurts and fermented milks during the past three decades and they are consumed at appropriate levels and as part of a balanced diet. In order to produce therapeutic benefits, a suggested minimum level for probiotic bacteria in fermented milk is from $10^{6}$ to $10^{7} \mathrm{cfu} \mathrm{mL}^{-1}$ [1]. Therefore, manufacturers are interested in developing process that can provide high densities of the probiotic strains in the product. For example, supplementing milk with a combination of protein hydrolysates, fructose whey protein concentrate, tomato juice and papaya pulp stimulated L. acidophilus, while cysteine, acid hydrolysates, tryptone, vitamins, dextrin and maltose improved the viability of Bifidobacteria. Prebiotics, such as oligosaccharides are added to food mainly to 
allow the preferential growth of probiotic organisms [2].

Inulin and oat fiber, the nondigestible carbohydrate containing naturally occuring fructooligosaccharides and $\beta$-glucan, respectively, possesses some characteristics of dietary fibers, and such is of particular interest for its metabolic properties [3] [4] [5]. Inulin and oat fiber are carbohydrate-derived fat replacers possessing gelling capacity with water and have low calories [6] [7]. Besides theirs health benefits, inulin and oat fiber are also considered to have prebiotic properties such as the ability to situmulate probiotic bacteria without affecting flavour [3] [8] [9]. Due to their prebiotic effect, addition of inulin or oat fiber can improve probiotic bacteria. There is, however, a low consumption of oat-based products, mainly due to the lack of acceptable and suitable food products [6]. Apricot is a rich source of sugars, fibers, minerals, bioactive phytochemicals and vitamins like A, C, thiamine, riboflavin, niacin and pantothenic acid [10] and could be used for formulations of dairy products. Apricot probiotic drinking yoghurt (APDY) can be used for this purpose.

The aim of this study was to establish the maximum level of fibre that could be incorporated into drinking yoghurt and thus, to produce an acceptable APDYs containing apricot and diatery fibers and high levels of probiotic bacteria $\left(>10^{6}-10^{7} \mathrm{cfu} \mathrm{g}^{-1}\right.$, which is the recommended minimum daily intake).

\section{Materials and Methods}

\subsection{Materials}

APDYs production were done in the Dairy Pilot Plant of the Food Engineering Department of Harran University. The cow milks were inoculated with mixed probiotic culture (FD-DVS ABT-2 Probio-Tec) consisting of Streptococcus thermophilus, Lactobacillus acidophilus and Bifidobacterium BB-12. The starter cultures were obtained from Peyma-Chr. Hansen (Turkey). Inulin and oat fiber were supplied from Arosel Gida (İstanbul). Apricot and sugar were purchased from markets. All reagents used in this work were of analytical grade and obtained from Sigma Chemicals (İstanbul, Turkey).

\subsection{Production of Apricot Probiotic Drinking Yoghurt (APDY)}

Drinking yoghurt was manufactured according to Tamime and Robinson [11]. Two different trials were performed for the manufacture of APDY. The fat of milks was standardized to $3 \%(\mathrm{w} / \mathrm{v})$ by separating cream and non fat dry matter contents of milks was standardized to $6 \%$ dry matter (w/v) by addition of water and homogenized at 175 bar. Milk was divided into seven equal portions (each 5 litres). The first batch (A) was control. Inulin was added to the second (A), third (B) and fourth (C) batches at a rate of $0.5 \%, 1 \%$ and $2 \%$, respectively. Oat fiber was added to the fifth (D), sixth (E) and seventh (F) batches at a rate of $0.5 \%, 1 \%$ and $2 \%$, respectively. After heat-treated at $90^{\circ} \mathrm{C}$ for $10 \mathrm{~min}$, milks cooled to $42^{\circ} \mathrm{C}$ and were inoculated with probiotic culture at a rate of $5 \%$ (about $10^{6} \mathrm{cfu} \mathrm{mL}^{-1}$ ) and the batches were incubated at $37^{\circ} \mathrm{C}$ until $\mathrm{pH}$ 4.6. On the other hand, one part of apricot puree was heated with one part of sugar $(w / w)$ at $90^{\circ} \mathrm{C}$ 
for $2 \mathrm{~min}$. After cooling it was added to probiotic fermented milk beverage at a rate of $10 \%$. Dry matter of APDYs were approximately between $13 \%$ and 15\%. After stirring with an electric mixer (Moulinex, France) for $3 \mathrm{~min}$ at low speed (less than $20 \mathrm{rpm}$ ), the bevarages dispensed into plastic cups $(200 \mathrm{ml})$ and closed with aluminum covers. Then they were transferred to a cold store $\left(4^{\circ} \mathrm{C} \pm 1^{\circ} \mathrm{C}\right)$ immediately.

\subsection{Chemical Analysis}

The $\mathrm{pH}$ of the milk and APDYs was measured using a digital pH-meter. Titratable acidity, expressed as $\mathrm{g}$ of lactic acid per $100 \mathrm{~g}$ APDY, was evaluated by titration method and the total fat contents were determined by the Gerber method, respectively [1]. The protein, moisture and ash contents of milk, and APDYs were estimated from the crude nitrogen content of the samples determined by the Kjeldahl, oven-drying and gravimetric methods, respectively [12].

\subsection{Physical Measurements}

The water holding capacity (WHC) was determined with a procedure adapted from Remeuf et al. [13]. A sample of about $20 \mathrm{~g}$ of native APDY was centrifuged for $10 \mathrm{~min}$ at $483 \times \mathrm{g}$ and $20^{\circ} \mathrm{C}$. The whey expelled (WE) was removed and weighed. The WHC was defined as WHC (\%) $=100$ (APDY-WE)/APDY.

The viscosity of the APDYs was determined at $4^{\circ} \mathrm{C}$ using a digital Brookfield Viscometer, Model DV-II (Brookfield Engineering Labrotories, Stoughton, MA, USA) [14].

Bacteriological analysis

APDY samples $(10 \mathrm{~g})$ were decimally diluted in $100 \mathrm{~mL}$ sterile peptone water $(0.1 \%)$ and $1 \mathrm{~mL}$ aliquot dilutions were poured onto plates of the various selective and differential agars in triplicate. S. thermophilus, L. acidophilus and Bifidobacterium BB-12 were incubated by using M17 agar, MRS with sorbitol agar and MRS-NNLP [1], respectively. All plates were incubated at $37^{\circ} \mathrm{C}$ for $72 \mathrm{~h}$. M17 was incubated aerobically, whereas all other media plates were incubated anaerobically. Anaerobic conditions were created using Anaerocult A sachets (Merck). Plates containing 20 - 200 colonies were counted and the results are expressed as colony-forming units per gram $\left(\mathrm{cfu} \mathrm{g}^{-1}\right)$ of sample.

\subsection{Sensory Assessment}

The samples were organoleptically assessed by ten panelists using a 9-point hedonic scale was used to evaluate flavour, texture, appearance and general acceptability ( $1=$ strongly unacceptable, $9=$ very good) as described by Bodyfelt $e t$ al. [15]. The panel of assessors was an external panel of non-smokers who were very familiar with fermented dairy products and were selected on the basis of sensory acuity and consistency. Judges developed a list of terms describing flavour and physical properties of yoghurt samples. The vocabulary comprised: (a) three attributes for colour and appearance (whey separation: non separated, slightly separated and too much separated and colour. normal, pale orange and dark orange) (b) three attributes for consistency (gel-like, too firm and too thin) (c) five attributes for flavour (intensity, acid/sour, sweet, flour flavour and 
other) (d) three attributes for general acceptability (very good, neither good not bad, very bad).

\subsection{Statistical Analysis}

The data were analysed statistically by means of SPSS statistical software program (version 5.0). Statistically different groups were determined by the LSD (Least Significant Difference) test [16].

\section{Results and Discussions}

\subsection{Physical and Chemical Characteristics}

The chemical composition of milk used for the production of APDY (data not shown) fell within the following averages: titratable acidity $0.18( \pm 0.01) \%$ as lactic acid (L. A.), $\mathrm{pH} 6.68( \pm 0.02)$, total solids $11.78 \%( \pm 0.06)$, fat $3.1 \%( \pm 0.03)$, protein $3.34 \%( \pm 0.07)$, lactose $4.58 \%( \pm 0.06)$ and ash $0.73 \%( \pm 0.01)$.

The changes of physico-chemical properties of APDY are shown in Table 1. Initial $\mathrm{pH}$ of milk (6.68) decreased to $4.15-4.62$ at $1^{\text {st }}$ day in APDYs. The $\mathrm{pH}$ values of the APDY samples contain fiber were lower and the acidity level were higher than control sample. The $\mathrm{pH}$ values of the APDY samples with inulin were lower and the acidity level of the APDY samples with inulin were higher than the samples with oat fiber. Gonzales et al. [17] reported that similar results in peach flavored yoghurt drinks made with prebiotic and probiotic bacteria from whole milk. With the increase in fiber content, $\mathrm{pH}$ values were slightly decreased and acidity level increased $(\mathrm{p}<0.01)$. The $\mathrm{pH}$ of the samples decreased and the acidity level increased continuously throughout storage period for all the samples. Guven et al. [18], Sahan et al. [19] and Sengul et al. [20] reported that titratable acidity increased during storage period in yoghurt made with fruits or fiber.

Addition of fiber had a positive effect on the WHC of APDYs. The highest WHC was obtained for sample $\mathrm{G}$, which fortified with $2 \%$ oat fiber. With the increase in fiber content, WHC values were increased $(\mathrm{p}<0.01)$. Oat fiber and inulin are highly hygroscopic, could bind water and form a gel-like network [3] [21].

Addition of fiber, especially oat fiber increased the viscosity of APDY $(p<0.01)$. The viscosity value of the sample $\mathrm{F}$ was the highest and the control sample was the least. Several authors reported that dietary fiber in fermented milk products increase the viscosity of the end product [18] [19] [22] [23]. According to Robinson [24], inulin would raise the viscosity as a consequence of the higher total solid content. A positive correlation was found between viscosity and fiber level of the samples $(\mathrm{p}<0.01)$. In general, the higher total solid content of milk, the higher viscosity values in the samples. Viscosity values of the samples increased during storage. It is known that depending on the decrease in $\mathrm{pH}$, the protein-protein interactions and therefore, slow protein rearrangements in the acid casein gels continue during cold storage [14]. Sahan et al. [19] were reported that viscosity values of the yoghurts with $\beta$-glucan were increased throughout storage. 
Table 1. The changes of physico-chemical properties of FMB during storage period.

\begin{tabular}{|c|c|c|c|c|c|}
\hline Sample* & Storage period & $\mathrm{pH}$ & Titratable acidity (\%L. A) & Viscosity (Cp) & Water holding capacity (\%) \\
\hline \multirow{4}{*}{$\mathrm{A}$} & 1.day & $4.62 \pm 0.049^{\mathrm{alA}}$ & $0.501 \pm 0.001^{\mathrm{c} 2 \mathrm{D}}$ & $1126 \pm 8.485^{\mathrm{d} 4 \mathrm{C}}$ & $77.91 \pm 1.216^{\mathrm{e3A}}$ \\
\hline & 7.day & $4.54 \pm 0.049^{\mathrm{alB}}$ & $0.535 \pm 0.006^{\mathrm{b} 2 \mathrm{C}}$ & $1170 \pm 19.799^{\mathrm{d} 3 \mathrm{~B}}$ & $77.08 \pm 1.386^{\mathrm{e3A}}$ \\
\hline & 14.day & $4.42 \pm 0.064^{\mathrm{a} 1 \mathrm{~B}}$ & $0.581 \pm 0.037^{\mathrm{c} 3 \mathrm{~B}}$ & $1200 \pm 22.627^{c 3 A}$ & $76.49 \pm 1.054^{\mathrm{d} 2 \mathrm{~A}}$ \\
\hline & 21.day & $4.33 \pm 0.035^{\mathrm{alC}}$ & $0.625 \pm 0.004^{c 3 \mathrm{~A}}$ & $1228 \pm 11.314^{\mathrm{c2A}}$ & $75.39 \pm 1.945^{22 \mathrm{~B}}$ \\
\hline \multirow{4}{*}{$\mathrm{B}$} & 1.day & $4.56 \pm 0.078^{\mathrm{a} 1 \mathrm{~A}}$ & $0.542 \pm 0.006^{\mathrm{blB}}$ & $1222 \pm 31.113^{\mathrm{c3C}}$ & $81.47 \pm 1.181^{\mathrm{d} 2 \mathrm{~A}}$ \\
\hline & 7.day & $4.49 \pm 0.085^{\mathrm{alA}}$ & $0.552 \pm 0.006^{\mathrm{b} 2 \mathrm{~B}}$ & $1260 \pm 11.314^{\mathrm{c} 2 \mathrm{~B}}$ & $79.90 \pm 0.79^{\mathrm{d} 2 \mathrm{~A}}$ \\
\hline & 14.day & $4.37 \pm 0.049^{\mathrm{a} 1 \mathrm{~B}}$ & $0.633 \pm 0.014^{\mathrm{b} 2 \mathrm{~A}}$ & $1308 \pm 5.657^{\mathrm{c} 2 \mathrm{~A}}$ & $77.95 \pm 1.301^{\mathrm{d} 2 \mathrm{~B}}$ \\
\hline & 21.day & $4.30 \pm 0.064^{\mathrm{blC}}$ & $0.651 \pm 0.029^{\mathrm{b} 2 \mathrm{~A}}$ & $1332 \pm 5.657^{\mathrm{b} 1 \mathrm{~A}}$ & $76.90 \pm 0.962^{22 B}$ \\
\hline \multirow{4}{*}{$\mathrm{C}$} & 1.day & $4.49 \pm 0.021^{\mathrm{b} 1 \mathrm{~A}}$ & $0.554 \pm 0.004^{\mathrm{alC}}$ & $1264 \pm 11.314^{\mathrm{b} 2 \mathrm{C}}$ & $88.35 \pm 1.937^{\mathrm{clA}}$ \\
\hline & 7.day & $4.38 \pm 0.035^{\mathrm{b} 2 \mathrm{~B}}$ & $0.585 \pm 0.005^{\mathrm{alB}}$ & $1290 \pm 8.485^{\mathrm{b} 2 \mathrm{~B}}$ & $86.64 \pm 2.220^{\mathrm{clA}}$ \\
\hline & 14.day & $4.30 \pm 0.021^{\mathrm{clB}}$ & $0.674 \pm 0.004^{\mathrm{a} 1 \mathrm{~A}}$ & $1330 \pm 2.828^{\mathrm{clA}}$ & $85.66 \pm 0.955^{\mathrm{clB}}$ \\
\hline & 21.day & $4.21 \pm 0.028^{\mathrm{clC}}$ & $0.688 \pm 0.011^{\mathrm{a} 1 \mathrm{~A}}$ & $1343 \pm 4.243^{\mathrm{b} 1 \mathrm{~A}}$ & $84.16 \pm 0.559^{\mathrm{d} 1 \mathrm{~B}}$ \\
\hline \multirow{4}{*}{$\mathrm{D}$} & 1.day & $4.46 \pm 0.0072^{\mathrm{b} 1 \mathrm{~A}}$ & $0.564 \pm 0.002^{\mathrm{alC}}$ & $1331 \pm 1.414^{\mathrm{a} 1 \mathrm{~A}}$ & $89.41 \pm 0.919^{\mathrm{clA}}$ \\
\hline & 7.day & $4.32 \pm 0.028^{\mathrm{b} 2 \mathrm{~B}}$ & $0.592 \pm 0.008^{\mathrm{alB}}$ & $1352 \pm 11.314^{\mathrm{alA}}$ & $88.38 \pm 0.742^{\mathrm{b} 1 \mathrm{~A}}$ \\
\hline & 14.day & $4.24 \pm 0.028^{\mathrm{c} 2 \mathrm{C}}$ & $0.678 \pm 0.002^{\mathrm{a} 1 \mathrm{~A}}$ & $1358 \pm 8.485^{\mathrm{b} 1 \mathrm{~A}}$ & $86.93 \pm 1.237^{\mathrm{clB}}$ \\
\hline & 21.day & $4.15 \pm 0.042^{\mathrm{d} 2 \mathrm{D}}$ & $0.697 \pm 0.010^{\mathrm{a} 1 \mathrm{~A}}$ & $1359 \pm 12.728^{\mathrm{a} 1 \mathrm{~A}}$ & $86.03 \pm 0.933^{\mathrm{clB}}$ \\
\hline \multirow{4}{*}{$\mathrm{E}$} & 1.day & $4.59 \pm 0.007^{\mathrm{alA}}$ & $0.548 \pm 0.005^{\mathrm{blC}}$ & $1280 \pm 11.314^{\mathrm{b} 2 \mathrm{~B}}$ & $91.59 \pm 0.785^{\mathrm{b} 2 \mathrm{~A}}$ \\
\hline & 7.day & $4.49 \pm 0.042^{\mathrm{alB}}$ & $0.571 \pm 0.025^{\mathrm{alC}}$ & $1294 \pm 14.142^{\mathrm{b} 2 \mathrm{~B}}$ & $89.89 \pm 1.117^{\mathrm{b} 2 \mathrm{~A}}$ \\
\hline & 14.day & $4.43 \pm 0.021^{\mathrm{alB}}$ & $0.616 \pm 0.008^{\mathrm{b} 1 \mathrm{~B}}$ & $1336 \pm 11.314^{\mathrm{b} 2 \mathrm{~A}}$ & $87.15 \pm 1.174^{\mathrm{b} 3 \mathrm{~B}}$ \\
\hline & 21.day & $4.36 \pm 0.028^{\mathrm{alC}}$ & $0.641 \pm 0.013^{\mathrm{c} 2 \mathrm{~A}}$ & $1358 \pm 2.828^{\mathrm{a} 1 \mathrm{~A}}$ & $85.03 \pm 0.127^{\mathrm{c} 3 \mathrm{C}}$ \\
\hline \multirow{4}{*}{$\mathrm{F}$} & 1.day & $4.54 \pm 0.021^{\mathrm{blA}}$ & $0.568 \pm 0.002^{\mathrm{a} 1 \mathrm{C}}$ & $1304 \pm 22.627^{\mathrm{alB}}$ & $93.12 \pm 1.259^{\mathrm{a} 1 \mathrm{~A}}$ \\
\hline & 7.day & $4.47 \pm 0.035^{\mathrm{blA}}$ & $0.587 \pm 0.007^{\mathrm{alC}}$ & $1350 \pm 8.485^{\mathrm{a} 1 \mathrm{~A}}$ & $91.95 \pm 0.870^{\mathrm{a} 1 \mathrm{~A}}$ \\
\hline & 14.day & $4.36 \pm 0.021^{\mathrm{blB}}$ & $0.621 \pm 0.008^{\mathrm{b} 1 \mathrm{~B}}$ & $1360 \pm 5.657^{\mathrm{blA}}$ & $89.69 \pm 1.711^{\mathrm{b} 2 \mathrm{~B}}$ \\
\hline & 21.day & $4.32 \pm 0.028^{\mathrm{alB}}$ & $0.657 \pm 0.016^{\mathrm{blA}}$ & $1376 \pm 0.000^{\mathrm{a} 1 \mathrm{~A}}$ & $88.63 \pm 0.594^{\mathrm{b} 2 \mathrm{~B}}$ \\
\hline \multirow{4}{*}{ G } & 1.day & $4.52 \pm 0.078^{\mathrm{b} 12 \mathrm{~A}}$ & $0.576 \pm 0.004^{\mathrm{alC}}$ & $1334 \pm 19.799^{\mathrm{alB}}$ & $94.11 \pm 1.351^{\mathrm{a} 1 \mathrm{~A}}$ \\
\hline & 7.day & $4.43 \pm 0.035^{\mathrm{blB}}$ & $0.584 \pm 0.006^{\mathrm{alC}}$ & $1362 \pm 14.142^{\mathrm{alA}}$ & $93.48 \pm 1.690^{\mathrm{a} 1 \mathrm{~A}}$ \\
\hline & 14.day & $4.32 \pm 0.021^{\mathrm{b} 2 \mathrm{C}}$ & $0.625 \pm 0.001^{\mathrm{b} 1 \mathrm{~B}}$ & $1388 \pm 5.657^{\mathrm{a} 1 \mathrm{~A}}$ & $92.21 \pm 2.524^{\mathrm{alB}}$ \\
\hline & 21.day & $4.27 \pm 0.014^{\mathrm{c} 2 \mathrm{C}}$ & $0.672 \pm 0.009^{\mathrm{b} 1 \mathrm{~A}}$ & $1384 \pm 5.657^{\mathrm{a} 1 \mathrm{~A}}$ & $91.06 \pm 1.803^{\mathrm{a} 1 \mathrm{~B}}$ \\
\hline
\end{tabular}

${ }^{*}$ A: Control, B: Fortified with inulin at 0.5\%, C: Fortified with inulin at 1.0\%, D: Fortified with inulin at 2.0\%, E: Fortified with oat fiber at $0.5 \%$, F: Fortified with oat fiber at $1.0 \%$, G: Fortified with oat fiber at $2.0 \%$; ${ }^{\mathrm{a}-\mathrm{d}}$ Different letters in the same column denote significant differences for fiber addition $(P<0.01)$. Different numbers in the same column denote significant differences for fiber rate storage period $(P<0.01)$. Different capital letters in the same column denote significant differences for storage period $(P<0.01)$.

\subsection{Bacterial Counts}

Viable bacterial counts of APDY samples during storage are shown in Table 2. Addition of fiber had no effect on the $S$. thermophilus counts of samples $(\mathrm{p}>0.05)$. Gee et al. [22], Vasiljevic et al. [25] and Kearney et al. [23] also reported that the addition of 
exogenous barley or oat $\beta$-glucan concentrates had no effect on the growth of yoghurt starter cultures. The counts of $S$. thermophilus raised slowly during the storage up to 14 day, and declined later about 0.5 - 0.8 log cycle. This could be due to the stimulated growth of Streptococcus species by essential amino acids occured during 14 day storage. After 14 days, lactic acid could made the environment unfavorable for the growth of Streptococcus species. Similar results were reported by Guler-Akin and Akin [1], Kearney et al. [23].

Table 2. The changes of viable bacteria counts of FMBs during storage period $\left(\log \mathrm{cfu} \mathrm{g}^{-1}\right)$.

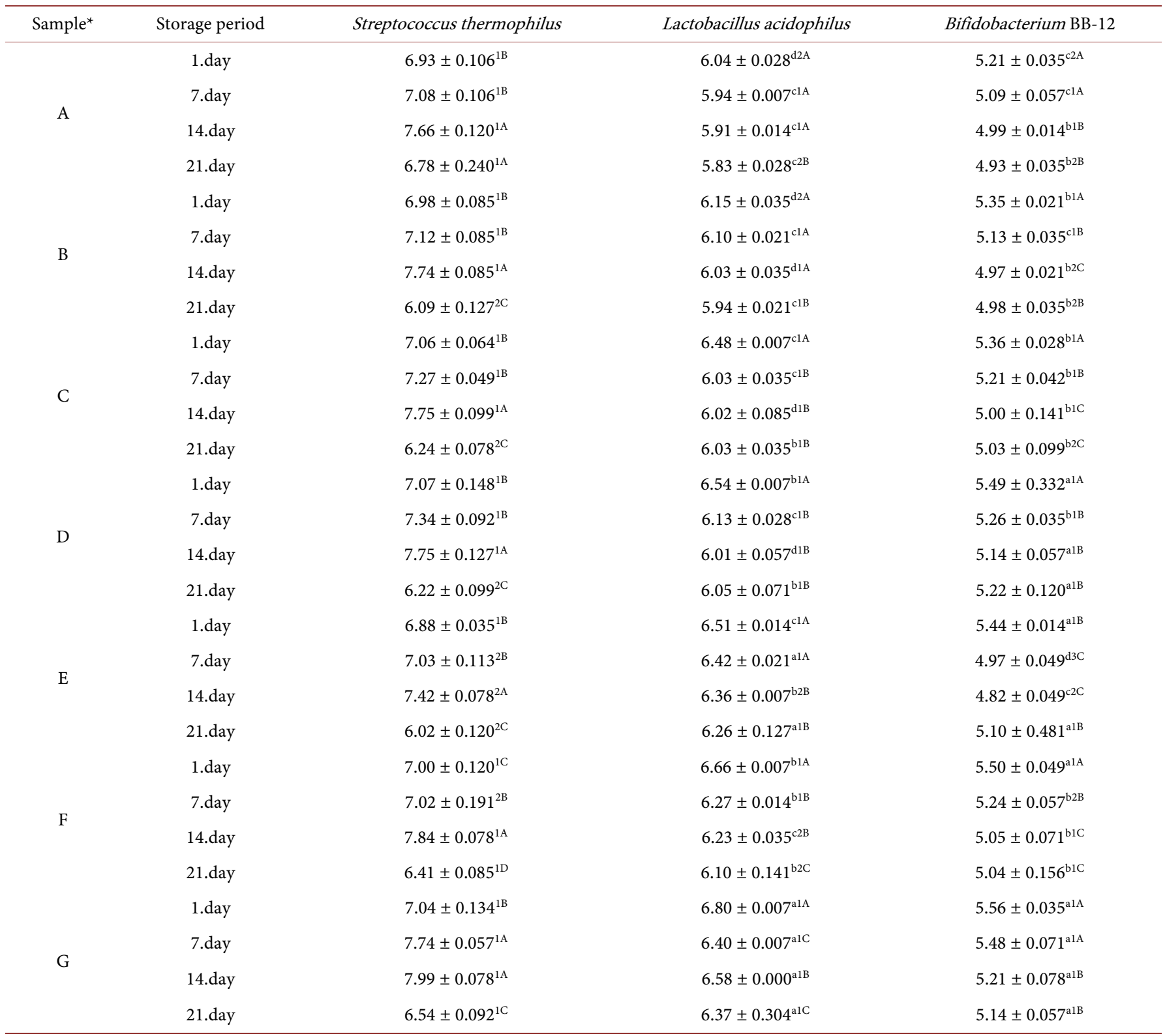

*A: Control, B: Fortified with inulin at $0.5 \%$, C: Fortified with inulin at 1.0\%, D: Fortified with inulin at 2.0\%, E: Fortified with oat fiber at $0.5 \%$, F: Fortified with oat fiber at $1.0 \%$, G: Fortified with oat fiber at $2.0 \%$; ${ }^{\mathrm{a}-\mathrm{d}}$ Different letters in the same column denote significant differences for fiber addition $(P<0.01)$. Different numbers in the same column denote significant differences for fiber rate storage period $(P<0.01)$. Different capital letters in the same column denote significant differences for storage period $(P<0.01)$. 
$L$. acidophilus counts of the samples fortified with oat fiber were higher than the other samples. Addition of inulin and oat fiber improve the viability of $L$. acidophilus. As increase in fiber content, $L$. acidophilus counts were increased $(\mathrm{p}<0.01)$. Previous studies have reported on the ability of probiotic and yoghurt starter cultures to break down and utilise $\beta$-glucan or inulin [22] [26] [27]. The counts of L. acidophilus decreased during storage period. One of the most important factor which affected the viability of $L$. acidophilus are acidity [28]. Acidity of the samples increased during the storage period. Similar results were reported by Guler-Akin and Akin [1].

Addition of fiber improved the viability of Bifidobacterium BB-12. Inulin is a prebiotic can stimulate the metabolism of LABs, which was metabolized as an additional carbon and energy source [29]. Sendra et al. [30] and de Souza et al. [31] reported that fiber or/and inulin addition had increased metabolic activity of the Bifidobacteria. In addition Gee et al. [22] and Snart et al. [26] reported that probiotic and yoghurt starter cultures can utilise $\beta$-glucan. According to the our results, oat fiber improved survival of bifidobacteria more than inulin. The higher fiber content, the higher Bifidobacterium $\mathrm{BB}-12$ counts in the samples $(\mathrm{p}<0.01)$. $\mathrm{pH}$ values of APDY samples reduced during the storage period under 4.5 which is the critical value for Bifidobacteria survival. Thus Bifidobacterium BB-12 counts declined during the storage period.

\subsection{Sensory Evaluations}

The sensory ratings for the APDYs for colour and appearance, consistency, aroma and general acceptability properties are detailed in Figures 1 (a)-(c), respectively. Because of growing yeast and mold, we couldn't make sensorial analysis at $21^{\text {st }}$ day of storage. The results on organoleptic evaluation indicated that the colour and appearance and consistency scores of APDYs with fiber received higher scores than the control samples $(\mathrm{p}<0.01)$. It could be related to decrease of whey speration in the samples with fiber. So their appearance was more homogenous than control samples. On the other hand, WHC increased in the samples with fiber and their firmness was improved. As the fiber rates increased the colour and appaerance and consistency scores of the samples increased, except sample G. We think that, addition of oat fiber at the rate of $2 \%$ caused too much water binding and concluded the sample $\mathrm{G}$ had an appearance and consistency like a yoghurt. Fernandez-Garcia et al. [32] reported that fiber addition to unsweetened yogurt improved the body and texture and decreased the quality overall flavour. The colour and appearance and consistency scores of samples decreased during storage. Similar resuls were reported by Sahan et al. [19].

The samples with inulin had the highest and the samples with oat fibers had the lowest aroma scores. Addition of inulin improved the aroma of APDYs. Güven et al. [18] had also reported that addition of inulin impoved the aroma of low-fat yoghurt. The panellists declared that flour flavour was feeled in the samples with oat fiber, especially in the samples fortified with $2 \%$ oat fiber. Sahan et al. [19] reproted that addition of $2 \%$ $\beta$-glucan influenced sensory scores of yoghurt negatively. Increase in fiber level caused to reduced in aroma scores of the samples. The aroma scores of the all samples 


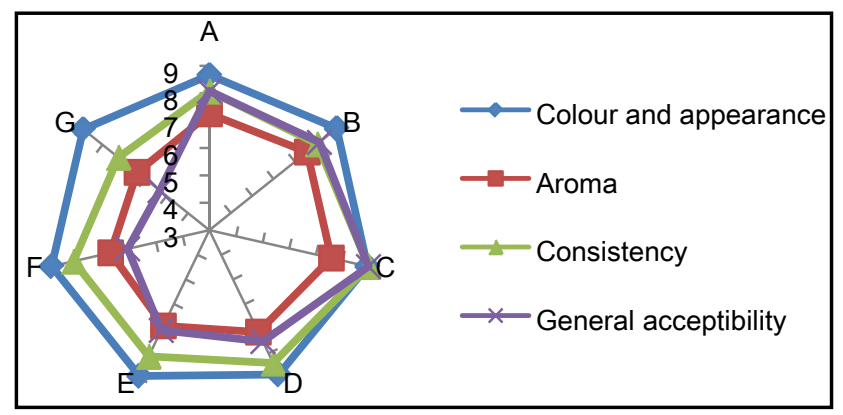

(a)

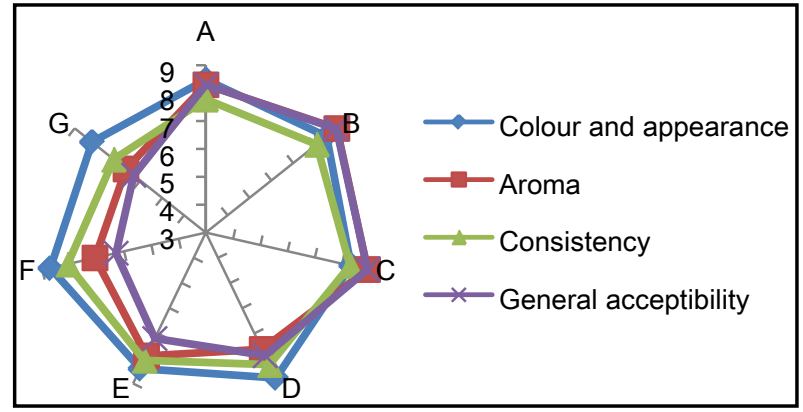

(b)

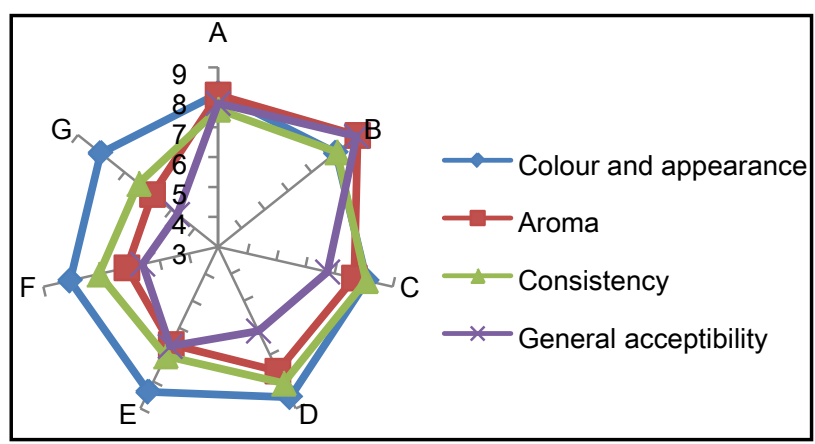

(c)

Figure 1. (a) Sensory profiles of the APYD at 1 day of storage; (b) sensory profiles of the APYD at 7 day of storage; (c) sensory profiles of the APYD at 14 day of storage.

increased during storage up to 7 day, and then decreased. At the beginning of storage, APDYs were more intensive flavour. This could be associated with development of acidity and decreases in acetaldehyde contents of the samples at the end of storage. Guven et al. [18] and Guler-Akin and Akin [1] reported that the acetaldehyde content was the lowest on day 14 in yogurt.

General acceptability scores of APDYs was influenced negatively by addition of fiber except sample B, which has $0.5 \%$ inulin $(\mathrm{p}<0.01)$. Sample B had the highest general acceptability scores. Similar results were found by Guven et al. [18] in low-fat yoghurt. With increased in fiber level general acceptability scores of the samples decreased. Srisuvor et al. [9] reported that high concentration of fiber could negatively affect the product's quality. The general acceptability scores of the samples decreased during storage. Similar results were found Guven et al. [18] and Sahan et al. [19] in fiber yoghurts. 


\section{Conclusions}

Addition of fiber improved physical properties of APDY such as viscosity and WHC. $\mathrm{pH}$ was lower, but titratable acidiy, viscosity and WHC were higher in APDY samples supplemented with oat fiber than the other samples. During the storage, whilst the $\mathrm{pH}$ and WHC values declined gradually, the titratable acidity and viscosity content increased at the same time.

While the counts of $S$. thermophilus weren't influenced by fiber, the counts of $L$. acidophilus and Bifidobacterium BB-12 were adversely affected by addition of fiber. The counts of L. acidophilus and Bifidobacterium BB-12 remained higher in APDYs supplemented with oat fiber than the other samples. Higher level of fiber supplementation led to an improvement in viability of $L$. acidophilus and Bifidobacterium BB-12. The viability of the probiotic bacteria was the highest in fortified with $2 \%$ oat fiber (sample G). During the storage, the viable counts of probiotics and $S$. thermophilus dropped in all samples. However the counts of $L$. acidophilus in all samples fortified with fiber were found to be above the threshold for therapeutic minimum $\left(10^{6}-10^{7} \mathrm{cfu}\right.$ $\left.\mathrm{g}^{-1}\right)$.

APDYs supplemented with inulin or oat fiber addition showed different sensory profile. Whilst addition of inulin improved sensory properties of APDYs, addition of oat fiber affected the aroma and general acceptability of APDYs negatively. The sample fortified with $0.5 \%$ inulin received the highest sensory scores from the panelists. During storage, total sensory scores of APDYs decreased.

Consequently, the use of inulin and oat fiber in APDY production could be recommended due to theirs prebiotic effects on probiotic bacteria and physical properties in APDYs and the maximum level of them could be $0.5 \%$.

\section{Acknowledgements}

This study was financially supported by the Research Fund of Harran University (Project No: 12153) and extracted from Ms. thesis of İsmet Ferliarslan.

\section{References}

[1] Güler-Akin, M.B. and Akin, M.S. (2007) Effects of Cysteine and Different Incubation Temperatures on the Microflora, Chemical Composition and Sensory Characteristics of BioYogurt Made from Goat's Milk. Food Chemistry, 100, 788-793. https:/doi.org/10.1016/j.foodchem.2005.10.038

[2] Lourens-Hattingh, A. and Viljoen, B.C. (2001) Yogurt as Probiotic Carrier Food. International Dairy Journal, 11, 1-17. https:/doi.org/10.1016/S0958-6946(01)00036-X

[3] El-Nagar, G., Clowes, G., Tudorica, C.M. and Kuri, V. (2002) Reological Quality and Stability of Yog-Icecream with Added Inulin. International Journal of Dairy Technology, 55, 89-93. https:/doi.org/10.1046/j.1471-0307.2002.00042.x

[4] Elleuch, M., Bedigian, D., Roiseux, O., Besbes S., Blecker, C. and Attia, H. (2011) Dietary Fiber and Fiber-Rich By-Products of Food Processing: Characterisation, Technological Functionality and Commercial Applications: A Review. Food Chemistry, 124, 411-421. https:/doi.org/10.1016/j.foodchem.2010.06.077 
[5] Meyer, D., Bayarri, S., Tárrega, A. and Costell, E. (2011) Inulin as Texture Modifier in Dairy Products. Food Hydrocolloid, 25, 1881-1890.

https:/doi.org/10.1016/j.foodhyd.2011.04.012

[6] Martensson, O., Osteb, R. and Holsta, O. (2002) The Effect of Yoghurt Culture on the Survival of Probiotic Bacteria in Oat-Based, Non-Dairy Products. Food Research International, 35, 775-784. https:/doi.org/10.1016/S0963-9969(02)00074-1

[7] De Moura, F.A., Pereira, J.M., Da Silva, D.O., Da Rosa Zavareze, E., Da Silveira Moreira, A., Helbig, E. and Dias, A.R.G. (2011) Effects of Oxidative Treatment on the Physicochemical, Rheological and Functional Properties of Oat $\beta$-Glucan. Food Chemistry, 128, 982-987. https:/doi.org/10.1016/j.foodchem.2011.04.003

[8] Ozer, D., Akın, M.S. and Ozer, B. (2005) Effect of Inulin and Lactulose on Survival of Lactobacillus acidophilus LA-5 and Bifidobacterium bifidum BB-02 in Acidophilus-Bifidus Yoghurt. Food Science and Technology International, 11, 19-24. https:/doi.org/10.1177/1082013205051275

[9] Srisuvor, N., Chinprahast, N., Prakitchaiwattana, C. and Subhimaros, S. (2013) Effects of Inulin and Polydextrose on Physicochemical and Sensory Properties of Low-Fat Set Yoghurt with Probiotic-Cultured Banana Puree. LWT - Food Science and Technology, 51, 30-36. https:/doi.org/10.1016/j.lwt.2012.10.018

[10] Ali, S., Masud, T. and Abbasi, K.S. (2011) Physico-Chemical Characteristics of Apricot (Prunus armeniaca L.) Grown in Northern Areas of Pakistan. Scientia Horticulture, 30, 386-392. https:/doi.org/10.1016/j.scienta.2011.05.040

[11] Tamime, A.Y. and Robinson, R.K. (1999) Yogurt Science and Technology. 2nd Edition, Woodhead Publishing Ltd., Cambridge.

[12] AOAC (1990) Official Methods of Analysis. 15th Edition, Association of Official Analytical Chemists, Arlington, Virginia.

[13] Remeuf, F., Mohammed, S., Sodini, I. and Tissierb, J.P. (2003) Preliminary Observations on the Effects of Milk Fortification and Heating on Microstructure and Physical Properties of Stirred Yoğurt. International Dairy Journal, 13, 773-782. https:/doi.org/10.1016/S0958-6946(03)00092-X

[14] Ozer, B., Robinson, R.K., Grandison, A.S. and Bell, A.E. (1997) Comparison of Techniques for Measuring the Rheological Properties of Labneh (Concentrated Yoghurt). International Journal of Dairy Technology, 50, 129-133. https:/doi.org/10.1111/j.1471-0307.1997.tb01753.x

[15] Bodyfelt, F.W., Tobias, J. and Trout, G.M. (1988) The Sensory Evaluation of Dairy Products. An Avi Book Published by Van Nostrand Reinhold, New York.

[16] Düzgüneş, O., Kesici, T., Kavuncu, O. and Gürbüz, F. (1987) Researches and Practice Methods (Statistical Methods II). AU Agricultural Faculty Publishes, Ankara, 1021.

[17] Gonzalez, N.J, Adhikari, K. and Sancho-Madriz, M.F. (2011) Sensory Characteristics of Peach-Flavored Yogurt Drinks Containing Prebiotics and Synbiotics. LWT-Food Science and Technology, 44, 158-163. http://dx.doi.org/10.1016/j.lwt.2010.06.008

[18] Guven, M., Yasar, K., Karaca, O.B. and Hayaloglu, A.A. (2005) The Effect of Inulin as a Fat Replacer on the Quality of Set-Type Low-Fat Yogurt Manufacture. International Journal of Dairy Technology, 58, 180-184. http://dx.doi.org/10.1111/j.1471-0307.2005.00210.x

[19] Sahan, N., Yasar, K. and Hayaloglu, A.A. (2008) Physical, Chemical and Flavour Quality of Non-Fat Yogurt as Affected by a Beta-Glucan Hydrocolloidal Composite during Storage. Food Hydrocolloid, 22, 1291-1297. http://dx.doi.org/10.1016/j.foodhyd.2007.06.010

[20] Sengul, M., Erkaya, T., Sengul, M. and Yildiz, H. (2012) The Effect of Adding Sour Cherry 
Pulp into Yoghurt on the Physicochemical Properties, Phenolic Content and Antioxidant Activity during Storage. International Journal of Dairy Technology, 65, 429-436. http://dx.doi.org/10.1111/j.1471-0307.2012.00838.x

[21] Pinero, M.P., Parra, K., Huerta-Leidenz, N., Arenas de Moreno, L., Ferrer, M., Araujo, S. and Barboza, Y. (2008) Effect of Oat's Soluble Fiber ( $\beta$-Glucan) as a Fat Replacer on Physical, Chemical, Microbiological and Sensory Properties of Low-Fat Beef Patties. Meat Science, 80, 675-680. http://dx.doi.org/10.1016/j.meatsci.2008.03.006

[22] Gee, V.L., Vasanthan, T. and Temelli, F. (2007) Viscosity of Model Yogurt Systems Enriched with Barley Beta-Glucan as Influenced by Starter Cultures. International Dairy Journal, 17, 1083-1088. http://dx.doi.org/10.1016/j.idairyj.2007.01.004

[23] Kearney, N., Stack, H.M., Tobin, J.T., Chaurin, V., Fenelon M.A., Fitzgerald, G.F., Ross, R.P. and Stanton, C. (2011) Lactobacillus Paracasei NFBC 338 Producing Recombinant Beta-Glucan Positively Influences the Functional Properties of Yoghurt. International Dairy Journal, 21, 561-567. http://dx.doi.org/10.1016/j.idairyj.2011.03.002

[24] Robinson, R.K. (1999) The Potential of Inulin as a Functional Ingredient. British Food Journal, 97, 30-33. http://dx.doi.org/10.1108/00070709510085657

[25] Vasiljevic, T., Kealy, T. and Mishra, V.K. (2007) Effects of Beta-Glucan Addition to a Probiotic Containing Yogurt. Journal of Food Science, 72, C405-C411. http://dx.doi.org/10.1111/j.1750-3841.2007.00454.x

[26] Snart, J., Bibiloni, R., Grayson, T., Lay, C., Zhang, H. and Allison, G.E. (2006) Supplementation of the Diet with High-Viscosity Beta-Glucan Results in Enrichment for Lactobacilli in the Rat Cecum. Applied and Environmental Microbiology, 72, 1925-1931. http://dx.doi.org/10.1128/AEM.72.3.1925-1931.2006

[27] Akin, M.B., Akin, M.S. and Kirmaci, Z. (2007) Effects of Inulin and Sugar Levels on the Viability of Yogurt and Probiotic Bacteria and the Physical and Sensory Characteristics in Probiotic Ice-Cream. Food Chemistry, 104, 93-99. http://dx.doi.org/10.1016/j.foodchem.2006.11.030

[28] Dave, R.I. and Shah, N.P. (1997) Viability of Yogurt and Probiotic Bacteria in Yogurts Made from Commercial Starter Cultures. International Dairy Journal, 7, 31-41. http://dx.doi.org/10.1016/S0958-6946(96)00046-5

[29] Mayo, B., Aleksandrzak-Piekarczyk, T., Fernandez, M., Kowalczyk, M., Alvarez-Martin, P. and Bardowski, J. (2010) Updates in the Metabolism of Lactic Acid Bacteria. In: Mozzi, F., Raya, R.R. and Vignolo, G.M., Eds., Biotechnology of Lactic Acid Bacteria: Novel Applications, Wiley-Blackwell, Ames, 3-33. http://dx.doi.org/10.1002/9780813820866.ch1

[30] Sendra, E., Fayos, P., Lario, Y., Fernandez-Lopez, J., Sayas-Barbera, E. and Perez-Alvarez, J. (2008) Incorporation of Citrus Fibers in Fermented Milk Containing Probiotic Bacteria. Food Microbiolog, 25, 13-21. http://dx.doi.org/10.1016/j.fm.2007.09.003

[31] De Souza Oliveira, R.P., Perego, P., de Oliveira, M.N. and Converti, A. (2011) Effect of Inulin as Prebiotic and Synbiotic Interactions between Probiotics to Improve Fermented Milk Firmness. Journal of Food Engineering, 107, 36-40. http://dx.doi.org/10.1016/j.jfoodeng.2011.06.005

[32] Fernandez-Garcia, E., McGregor, J.U. and Traylor, S. (1998) The Addition of Oat Fiber and Natural Alternative Sweeteners in the Manufacture of Plain Yogurt. Journal of Dairy Science, 81, 655-663. http://dx.doi.org/10.3168/jds.S0022-0302(98)75620-6 
Submit or recommend next manuscript to SCIRP and we will provide best service for you:

Accepting pre-submission inquiries through Email, Facebook, LinkedIn, Twitter, etc. A wide selection of journals (inclusive of 9 subjects, more than 200 journals)

Providing 24-hour high-quality service

User-friendly online submission system

Fair and swift peer-review system

Efficient typesetting and proofreading procedure

Display of the result of downloads and visits, as well as the number of cited articles

Maximum dissemination of your research work

Submit your manuscript at: http://papersubmission.scirp.org/

Or contact aim@scirp.org 